\title{
Cross-Sector Style Analysis Of Global Equities Based On The Fama And French Three-Factor Model
}

Heng-Hsing Hsieh, PhD, CFA, University of the Western Cape, South Africa Kathleen Hodnett, PhD, University of the Western Cape, South Africa

\begin{abstract}
Although the ability of the Fama and French (1993) 3-factor model in explaining style-based portfolio returns have been widely tested, no such test has been conducted on sector-based portfolios. The study conducted by Hsieh and Hodnett (2011) indicate that the resource sector yields significant abnormal returns under the capital asset pricing model (CAPM) over the period from 1999 to 2009. In addition, the book value-to-market ratio and market capitalization are found to have pervasive effects on the pricing of sector returns for global equities. Motivated by this insight, we undertake to test the ability of the Fama and French (1993) 3-factor model in explaining the variations in the global sector returns. Our test results indicate that the market risk premium is the most significant factor that drives the returns in all sectors under review. Although the positive abnormal returns of the resource sector dissipates under the 3-factor model, the industrial sector and the information technology (I.T.) sector yield abnormal returns under the 3factor model. Unlike the empirical findings on the style portfolios, the signs and statistical significance of the exposures to the value and size risk premiums are not consistent across all sectors. This finding suggests that sector exposures are more unique and distinctive compared to the style portfolios. It could be argued that since most of the style portfolios are directly related to the value and size anomalies, any factor model that incorporates risk premiums on these anomalies would significantly explain the style portfolio returns. However, the ability of such factor model in explaining returns on portfolios formed using methodologies other than style anomalies, such as sector portfolio returns, would be questionable. Taking into account the rising global integration, sector allocation might be more effective in terms of global active portfolio management or international diversification than style allocation and country allocation.
\end{abstract}

Keywords: Sector Allocation; Value Effect; Small Firm Effect; Market Anomalies; Return Attribution; Global Equities; Capital Asset Pricing Model (CAPM); Fama And French

\section{INTRODUCTION}

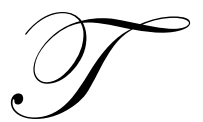

he capital asset pricing model (CAPM) of Sharpe (1964) and Lintner (1965) postulates that the only relevant risk in asset pricing is systematic risk. Firm-specific factors such as differences in firm size or the price-earnings multiple are regarded as unsystematic and can be diversified away in a large portfolio under the notion of the CAPM. The market risk premium (that is, the market return in excess of the riskfree rate of return) is the only explanatory factor employed by the CAPM to estimate asset returns. The sensitivity of an asset's returns to movements in the market risk premium is computed as the beta coefficient that measures the systematic exposure of the asset. The higher the beta coefficient, the higher is the required rate of return for the asset.

Empirical research has identified several anomalies relating to pricing assets using the CAPM. The small firm effect and the value effect, amongst other anomalies, are the most prominent anomalies documented in empirical literature. The small firm effect, known as the size anomaly, refers to the phenomenon where firms with 
smaller market capitalization generally outperform larger firms. The value effect refers to the phenomenon where firms with lower price-to-fundamental multiples (such as the price-to-earnings ratio or the price-to-book value ratio) are found to outperform firms with higher price-to-fundamental multiples. According to empirical literature, the abnormal returns earned by small firms and value stocks cannot be explained by the market risk premium alone using the CAPM.

Fama and French (1993) argue that small caps and value stocks are riskier compared to large, more established firms with good growth prospects. Based on this argument, Fama and French (1993) incorporate the small firm risk premium and the value risk premium in addition to the market risk premium to explain returns on portfolios formed based on various empirical anomalies. The 3 -factor model is found to explain most of the anomalies adequately.

Because anomalies are broadly followed by asset managers to form their distinctive investment styles, portfolios formed based on empirical anomalies are termed style portfolios. Although the validity of the 3 -factor model of Fama and French (1993) in explaining style portfolio returns is well documented by empirical literature, tests of the 3 -factor model have not yet been conducted on the sector-based portfolios. The study conducted by Hsieh and Hodnett (2011) reveals that the abnormal returns on the basic materials and oil and gas sector over the past 10 years cannot be explained by the CAPM. The results of the univariate test, based on the Fama and MacBeth (1973) model, also shows that the size and value effects are prominent in each of the sector portfolios. Built on this insight, we attempt to explain the sector returns for global equities using the 3-factor model of Fama and French (1993). The same sector classification, database and examination period adopted by Hsieh and Hodnett (2011) are applied to this research.

The coefficients obtained from the 3-factor model provide valuable information regarding the influences of the market risk premium, small firm premium and value risk premium on different sector returns. The joint influences of the market risk, firm size and value effect can thus be established and compared to the univariate results of Hsieh and Hodnett (2011) on sector portfolios of global equities.

\section{LITERATURE REVIEW}

Basu (1977) tests the effect of the price-to-earnings ratio on U.S. stock returns over the period from 1957 to 1971. Using stocks with low price-to-earnings ratio as the proxy for value stocks, Basu (1977) finds that stocks with relatively lower price-to-earnings ratio outperform stocks with higher price-to-earnings ratio, on a risk-adjusted basis. Lakonishok, Shleifer and Vishny (1994) extend the studies of the value effect to include book value-to-market ratio, cash flow-to-price ratio, earnings yield and historical sales growth over the period from 1963 to 1990. Test results reveal that value stocks that have relatively higher book value-to-market ratio, higher cash flow-to-price ratio, higher earnings yield and lower historical sales growth outperform growth stocks.

With regard to the size effect, Banz (1981) tests the effect of firm size on U.S. stock returns over the period from 1927 to 1975. After controlling for market risk in the sample, Banz (1981) finds that firms with relatively smaller market capitalization (small caps) outperform firms with relatively larger market capitalization (large caps). Other well established CAPM anomalies include the mean reversion of long-term winner and loser portfolios discovered by De Bondt and Thaler $(1985 ; 1987)$ and the abnormal returns of short-term momentum portfolios documented by Jegadeesh and Titman (1993).

Fama and French (1993) argue that the value and size anomalies represent potential risks in the portfolio, and investors anticipate compensation for holding value stocks and small caps. Built on this insight, Fama and French (1993) propose a 3-factor asset pricing model that incorporates the size risk premium and the value risk premium, in addition to the market risk premium of the CAPM. The size risk premium is calculated as the small cap returns minus the large cap returns. On the other hand, the value risk premium is calculated as the return difference between the portfolio with high book-to-market ratio and the portfolio with low book-to-market ratio. The 3-factor model is found to explain most of the style portfolio returns better than the CAPM. Fama and French (1993) conclude that since the empirical anomalies are proxied by firm-specific attributes that are scaled versions of a firm's value, it is expected that the effects of some anomalies are subsumed by the effects of other anomalies. 
The Fama and French (1993) 3-factor model is generally found to improve the explanatory power of the CAPM significantly in international studies. Maroney and Protopapadakis (2002) attempt to explain the effects of the book-to-market ratio and market capitalization using a stochastic discount factor (SDF) model on international stocks in Australia, Canada, Germany, France, Japan, the United Kingdom and the United States of America (U.S.). They find the value and size abnormal returns to persist under the SDF model.

Drew and Veeraraghavan (2002) test the significance of the value and size risk premiums on Malaysian stocks. Their results show that both the value and size risk premiums are significant throughout the examination period from 1993 to 1999. Drew and Veeraraghavan (2003) extend their prior research to test the pricing power of the Fama and French (1993) 3-factor model on South-East Asian stocks in Hong Kong, Korea, Malaysia and the Philippines. Their results indicate that the 3-factor model outperforms the market model in explaining the SouthEast Asian stock returns. Gaunt (2004) tests the explanatory power of the Fama and French (1993) 3 -factor model on the Australian Securities Exchange (ASX) over the period from 1981 to 2000. Test results suggest that the 3factor model provides significant improvements over the CAPM over the examination period.

When the effects of the empirical anomalies are examined within each of the global equity sectors, Hsieh and Hodnett (2011) find the effects of the book value-to-market ratio and market capitalization to be pervasive in differentiating stock returns in each sector over the period from 1999 to 2009 under the univariate test. Firms with relatively higher book-to-market ratio are found to outperform firms with relatively lower book-to-market ratio over the examination period. On the other hand, firms with relatively larger market capitalizations tend to accumulate negative abnormal returns over the examination period.

\section{DATA AND METHODOLOGY}

The Dow Jones (DJ) Sector Titans Composite Index is used as the database for this research. As recommended by Hsieh and Hodnett (2011), this database provides sufficient exposures to the largest 30 international firms (by market capitalization) from each of the 19 sectors defined by the Industry Classification Benchmark (ICB). An additional advantage of this database is that it includes firms from both developed and emerging economies, as opposed to the Morgan Stanley Capital International (MSCI) Index that only includes firms from developed economies.

The monthly historical prices, total return indexes, number of outstanding common stocks, market capitalization and per share book value of the 570 stocks comprising the DJ Sector Titans Composite Index, over the period from 01 January 1996 to 31 December 2009, are obtained from DataStream International as of 01 March 2010. All attribute values are converted into U.S. dollars over the examination period. Due to the fact that DataStream International only records data as they arrive, the research database is not subject to look-ahead bias. The survivorship bias is partially mitigated by the fact that only the most established firms that are less likely to be non-survivors in their respective industries are included in the research sample.

The 19 Sectors covered by the DJ Sector Titans Composite Index include automobiles and parts, banks, basic resources, chemicals, construction and materials, financial services, food and beverages, health care, industrial goods and services, insurance, media, oil and gas, personal and household goods, real estate, retail, technology, telecommunication, travel and leisure and utilities. Following the methodology of Hsieh and Hodnett (2011), sample stocks from the 19 sectors are subdivided into 7 dominant categories, namely basic materials and oil and gas (BMOG), consumer goods and services (CGCS), banking and financials (BNFN), healthcare (HLCR), industrials (INDL), technology and telecommunications (TGTL) and utilities (UTLT). The sector portfolios are constructed by allocating equal weights to constituent stocks in the respective sectors at the beginning of each month (that is, the sector portfolios are rebalanced on a monthly basis) over the examination period.

The monthly-rebalanced, equal-sector-weighted index and the 3-month Treasury bill are employed as the market proxy and the risk-free asset in this research. Hsieh and Hodnett (2011) suggest that using an equal-sectorweighted market proxy ensures fair representation of each sector in the proxy. The Fama and French (1993) model is demonstrated in Equation 1: 


$$
r_{P, t}-r_{f, t}=\alpha_{P}+\beta_{P} \times\left(r_{m, t}-r_{f, t}\right)+s_{P} S M B_{t}+h_{P} H M L_{t}+\varepsilon_{P, t}
$$

Where:

$r_{P, t} \quad$ is the return on the sector portfolio $P$ in month $t$;

$r_{f, t} \quad$ is the return on the 3 -month U.S. Treasury bill in month $t$;

$r_{m, t} \quad$ is the return on the MSCI World Index in month $t$;

$\beta_{P} \quad$ is the beta coefficient of the regression measuring the sensitivity of sector portfolio $P$ 's returns to variations in the market risk premium; and

$s_{i} \quad$ is the sensitivity of sector portfolio $P$ 's return to variations in the size risk premium $S M B$;

$h_{i} \quad$ is the sensitivity of sector portfolio $P$ 's return to variations in the value risk premium $H M L$;

$\varepsilon_{P, t} \quad$ is the regression residual representing the abnormal returns of sector portfolio $P$ in month $t$.

The size risk premium, $S M B$, is computed as the return on the small cap portfolio less the return on the large cap portfolio. The value risk premium, $H M L$, is computed as the return on the high book-to-market portfolio minus the return on the low book-to-market portfolio. The small and large firm portfolios are constructed by selecting the largest and the smallest 50 firms based on their market capitalization at the beginning of each month. On the other hand, the high and low book-to-market portfolios are constructed by selecting 50 firms with the highest and the lowest book-to-market ratio at the beginning of each month. The monthly time-series of the market risk premium, $S M B$ and $H M L$ are estimated over the examination period.

When the time-series excess returns on a sector portfolio is regressed on the time-series risk premiums, the exposure to each of the risk factors are estimated with the intercept indicating the consistent outperformance/underperformance of a sector over its risk-adjusted returns. Examining the exposures to risk premiums contributes to the identification of the major sources of risks that drive the returns on the various sector portfolios.

\section{EMPIRICAL FINDINGS}

The log cumulative market risk premium, size risk premium and value risk premium over the examination period are illustrated in Figure 1. The risk premiums can be regarded as the returns on zero investment portfolios constructed from market neutral strategies based on the exposures to specific risk factors: the market risk premium represents the return on a market neutral strategy that longs the equity market and shorts the risk-free asset (a preference of market risk over a risk-free investment); the size risk premium can be considered as the return earned by a market neutral strategy that longs the small firm portfolio and simultaneously shorts the large firm portfolio (a preference of small firms over large firms); and the value risk premium is the return on a market neutral strategy that longs the value portfolio and shorts the glamour portfolio (a preference of value stocks over glamour stocks).

The most consistent risk premium in Figure 1 over the examination period is the size risk premium. The value risk premium appears to be negatively correlated to investor sentiment. The value risk premium is negative during the market over-optimism during the peak of the I.T. bubble and turns strongly positive when the I.T. bubble bursts in 2000. When the global equity market starts to take off from the trough of the bear trend in the mid-2000s, the value risk premium becomes less significant until the global financial crisis of 2008.

Table 1 reproduces the summary of the performances of the global sector portfolios documented by Hsieh and Hodnett (2011) over the examination period. The consumer goods and services sector (CGCS), the healthcare sector (HLCR) and the utilities sector (UTLT) represent defensive industries with relatively lower risk and returns compared to the other sectors. The basic materials and oil and gas sector (BMOG) and the banking and financial sector (BNFN) represent sectors with relatively higher risk and returns amongst other sectors. The examination of the $t$-statistic of Jensen's alpha indicates that BMOG is the only sector that earns significant positive abnormal returns that cannot be explained by the market risk premium of the CAPM. 


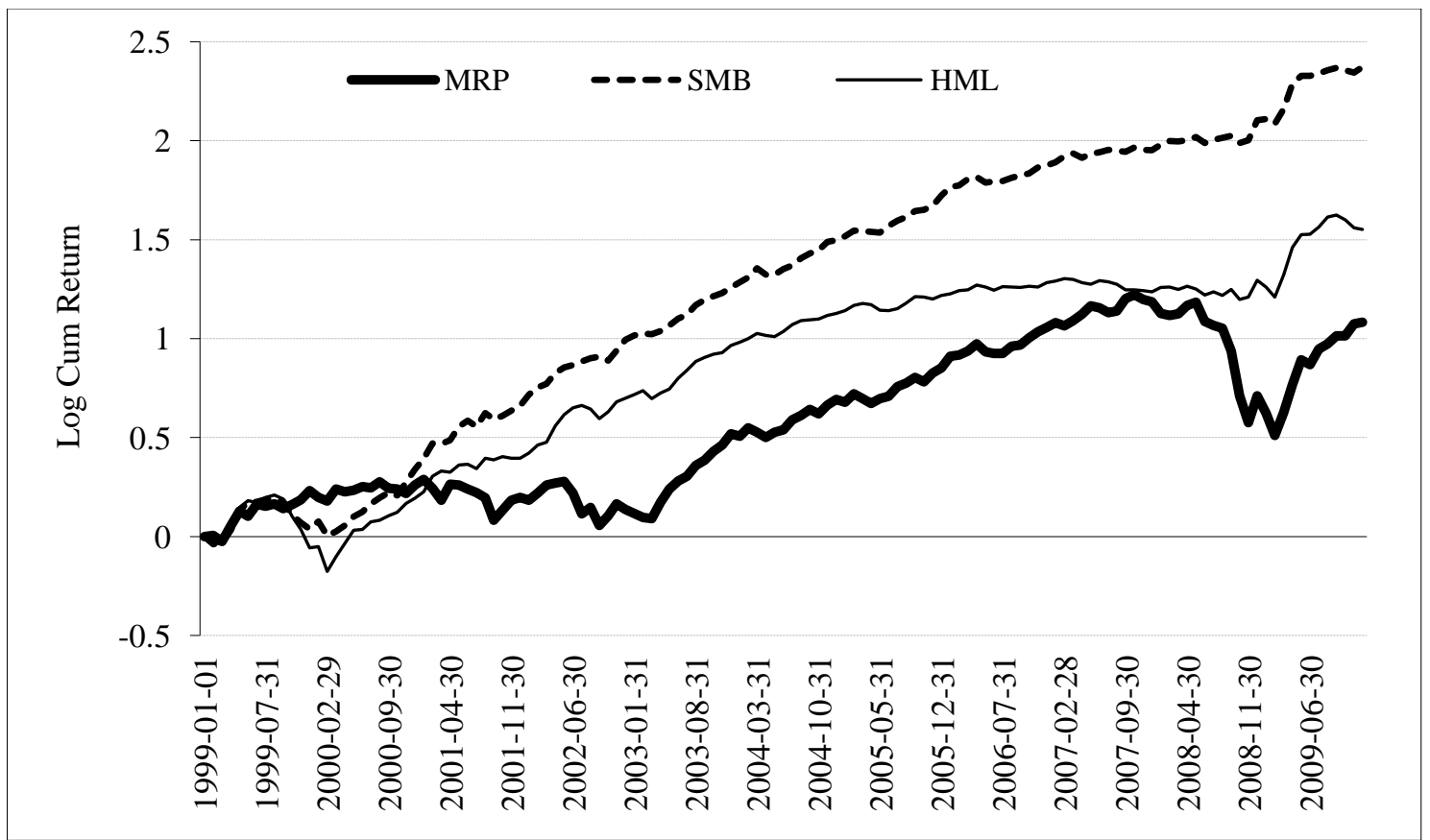

Figure 1: Log Cumulative Risk Premiums

Table 1: Global Sector Portfolio Performance Summary (1999 to 2009)

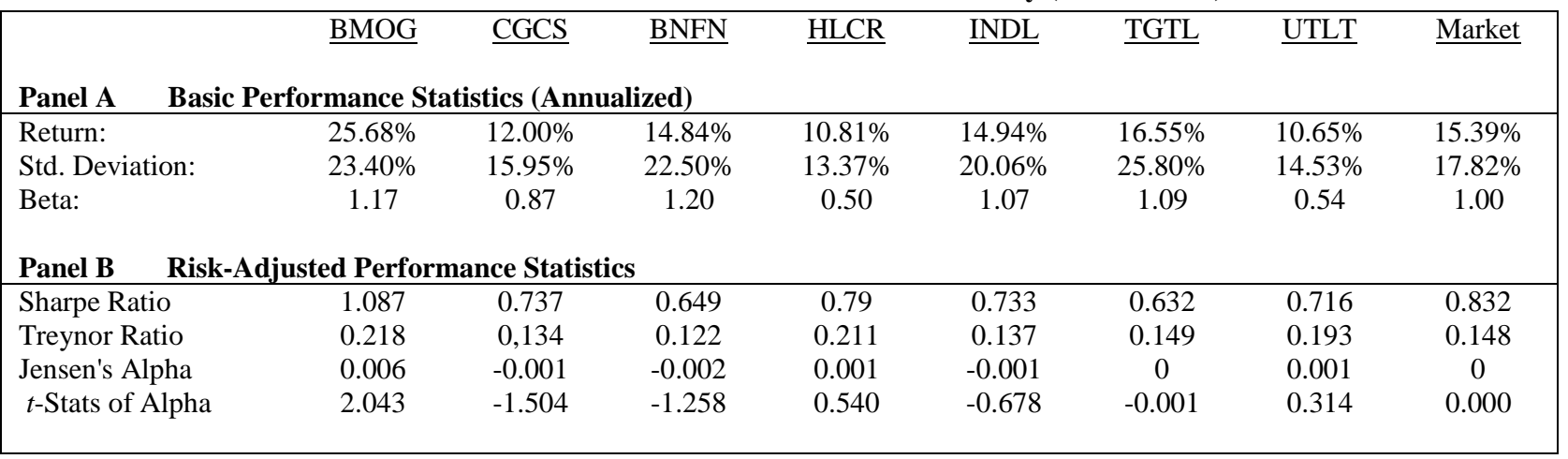

* This Table is adapted and modified from Hsieh and Hodnett (2011).

Figure 2 plots the relative risk-return positions of the global sector portfolios and the market proxy against the capital market line (CML). Using standard deviation as the relevant measure of risk, BMOG is the only sector that outperforms its respective risk-adjusted return. With the exception of BMOG, all the global sector portfolios underperform the market proxy in terms of their Sharpe ratios (refer to Panel B of Table 1). The technology and telecommunication sector (TGTL), the sector with the lowest Sharpe ratio of 0.632 over the examination period, is furthest from the CML amongst other sectors in Figure 2.

Figure 3 illustrates the relative positions of the global sector portfolios and the market proxy against the security market line (SML) under the notion of the CAPM. When the relevant risk is measured by the beta coefficient (a measure of systematic risk), HLCR and UTLT, the two defensive sectors and BMOG are plotted above the SML. The underperformance of TGTL observed in Figure 2 dissipates in Figure 3, which indicates that a large portion of the risk inherent in TGTL is unsystematic and diversifiable when combined with other sectors. This finding implies that stocks in TGTL have unique risk orientation compared to stocks in other sectors. BMOG remains the best performing sector with the furthest distance from the SML in Figure 3. 


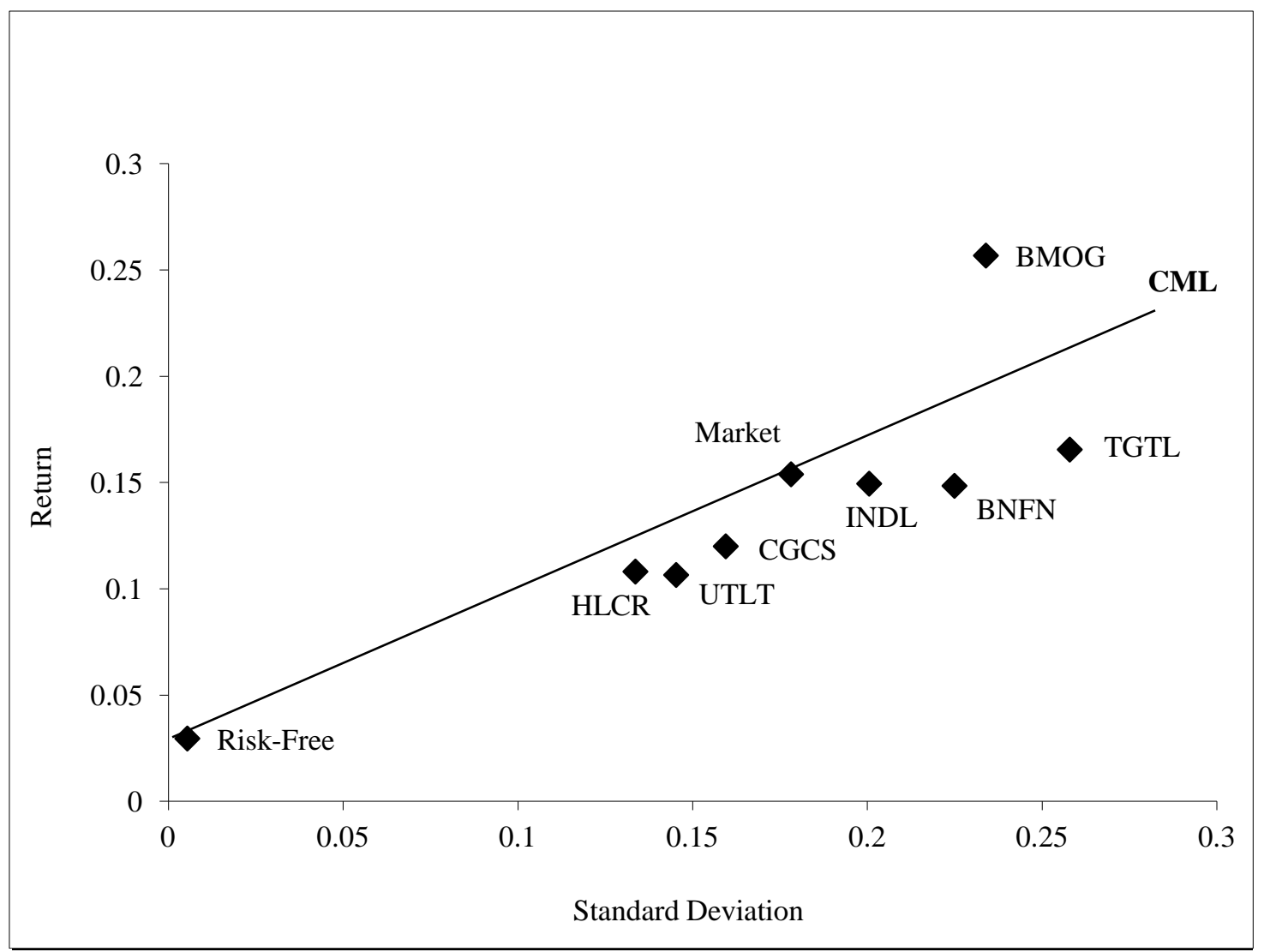

Figure 2 Sector Portfolios and the Capital Market Line

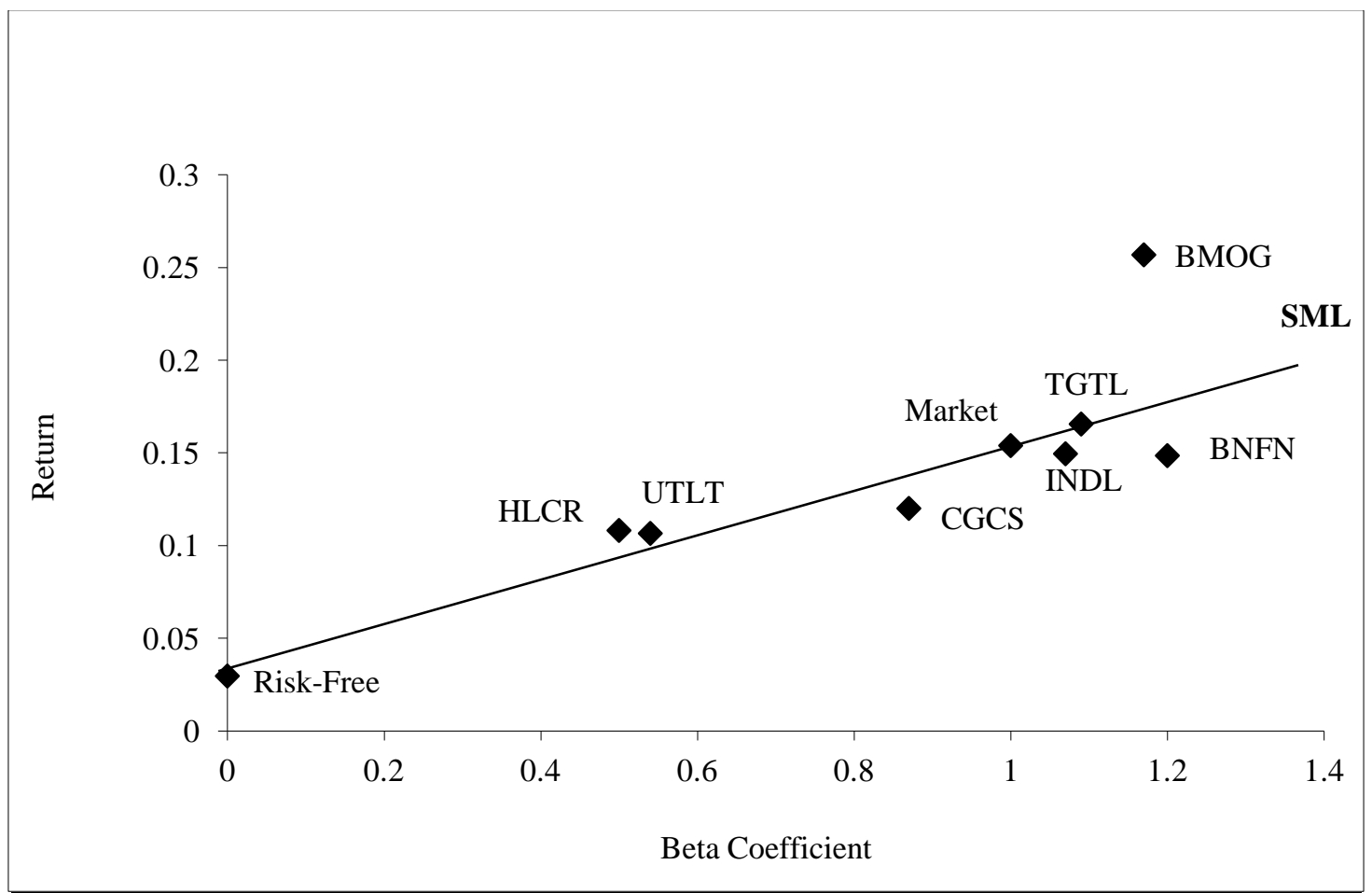

Figure 3 Sector Portfolios and the Security Market Line 
Table 2 demonstrates the time-series regression results when the Fama and French (1993) 3-factor model is applied to each of the pre-specified sector portfolios of global equities. The explanatory power of the 3 -factor model indicated by R-squared and the adjusted R-squared are shown in Panel A of Table 2. Panel B of Table 2 displays the intercept and the exposures of the sector portfolios to variations in respective risk premiums. The $t$-statistics of the coefficients are shown in parentheses. Coefficients that are statistically significant at a 5\% level are highlighted in bold.

An examination of the significance of the regression intercept indicates that the significant abnormal return of BMOG dissipates under the notion of the 3-factor model. Although the size risk premium contributes significantly in explaining the returns of BMOG, the value risk premium seems to negatively affect the returns of BMOG to a moderate degree. TGTL is the other sector that exhibits negative exposure to the value risk premium. In addition, the exposure to the size risk premium for TGTL is also negative. This indicates that after taking into account the systematic risks inherent in TGTL, value stocks and large caps within the I.T. sector actually underperform glamour stocks and large caps within the sector, on a risk-adjusted basis, under the notion of the 3factor model.

The inconsistencies of the exposures to the size and value risk premium are also observed among other global equity sectors. The sectors that exhibit negative exposure to the size risk premium other than TGTL include CGCS, BNFN and HLCR. Although INDL and UTLT exhibit positive exposures to the size risk premium, the exposures are not statistically significant. With regard to the value risk premium, BNFN and TGTL are the only sectors that have significant exposures to the value risk premium. By contrast, the exposures of all sectors to the market risk premium are all significantly positive. The examination of the $t$ statistics of the coefficients indicates that the market risk premium is the most important factor that drives the returns across all sectors under review.

Table 2: Global Sector Portfolio Return Attribution (1999 to 2009)

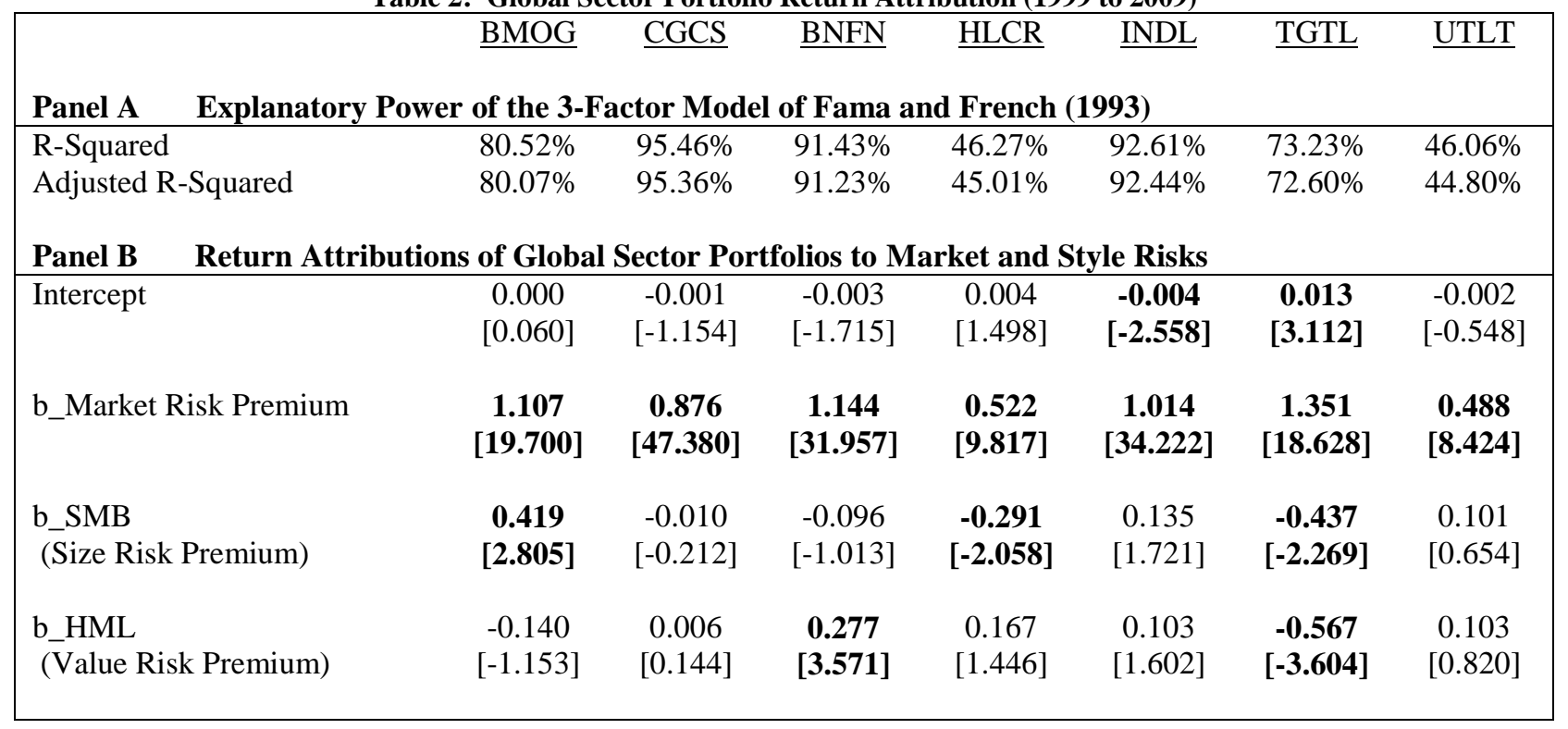

\section{CONCLUSION}

The examination of the cumulative risk premiums indicates that the size risk premium is the most consistent risk factor over the examination period. The value risk premium seems to be related to the economic cycle in that it is more significant during turbulent times and weaker during the bull market. This suggests that value stocks are a safe haven during financial market turmoil but are neglected by investors in the upswing of the economic cycle. 
The evaluation of the risk-adjusted performances of the sector portfolios indicates that a large portion of the volatility inherent in the I.T. sector, the healthcare sector and the utility sectors seems to be unsystematic in nature. When the unsystematic risk is removed from the equation, the underperformance of the I.T. sector dissipates and the defensive healthcare and utility sector outperform their respective risk-adjusted returns under the notion of the CAPM.

When the Fama and French (1993) 3-factor model is applied to the sector portfolio of global equities, the market risk premium appears to be the most important factor that explains the returns across all sector portfolios. Although the value and size effects are persistent across sector portfolios in the univariate study of Hsieh and Hodnett (2011), they seem to be subsumed by the variations in the market risk premium in the multivariate analysis.

While the exposures to the market risk premium are positively significant for all sector portfolios, the exposures to the value and size risk premiums are inconsistent across all sectors. This finding contradicts the success of the Fama and French (1993) 3-factor model in explaining style portfolio returns documented by empirical studies. A possible explanation for this result could be that the value and size risk premiums of the Fama and French (1993) 3 -factor model are derived directly from the value and size anomalies. Due to the fact that the style portfolios are mostly derived from the value and size related attributes, using any factor model that includes some sort of premium on the value and size risks would have significant power in explaining style portfolio returns. On the other hand, if one were to apply the Fama and French (1993) 3-factor model to explain the returns of the portfolios formed based on methodologies other than the value and size anomalies, such as different sector returns, the explanatory power of the model might become questionable.

Taking into account the rising global integration, sector allocation might be more effective in terms of global active portfolio management or international diversification than style allocation and country allocation. We recommend studies that explore the potential benefits of sector allocations in the global equity market as area requiring further research.

\section{ACKNOWLEDGEMENT}

This research is supported by the National Research Foundation (NRF) of South Africa. We thank the research office of the University of the Western Cape for the support of this research project.

\section{AUTHOR INFORMATION}

Dr. Heng-Hsing Hsieh, CFA is the Head of Finance in the School of Business and Finance at the University of the Western Cape, South Africa. He is a CFA charterholder and a member of the South African Institute of Financial Markets (SAIFM). E-mail: ahsieh@uwc.ac.za. Corresponding Author.

Dr. Kathleen Hodnett is currently a Research Fellow (funded by the National Research Foundation (NRF) of South Africa) in the School of Business and Finance at the University of the Western Cape, South Africa. She is a member of the International Institute of Forecasters (IIF) and an associate member of the South African Institute of Financial Markets (SAIFM).

\section{REFERENCES}

1. Arnott, R. D., Hsu, J. and Moore, P. (2005) 'Fundamental Indexation', Financial Analysts Journal, 61(2), 83-99.

2. Banz, R. W. (1981) 'The Relationship between Return and Market Value of Common Stocks', Journal of Financial Economics, 9, 3-18.

3. Basu, S. (1977) 'The Investment Performance of Common Stocks in Relation to Their Price to Earnings Ratio: A Test of the Efficient Markets Hypothesis', Journal of Finance, 32(3), 663-682.

4. Bauman, C., Conover, C. M. and Miller, R. E. (1998) 'Growth versus Value and Large-Cap versus SmallCap Stocks in International Markets', Financial Analysts Journal, 54(2), 75-89. 
5. Bekaert, G. and Harvey, C. R. (1995) ‘Time-Varying World Market Integration’, Journal of Finance, 50(2), 401-444.

6. Carhart, M. M. (1997) 'On Persistence in Mutual Fund Performance', Journal of Finance, 52(1), 57-82.

7. Cavaglia, S. and Moroz, V. (2002) 'Cross-Industry, Cross-Country Allocation', Financial Analyst Journal, 58(6), 78-97.

8. Chan, K. C., Hameed, A. and Tong, W. (2000) 'Profitability of Momentum Strategies in the International Equity Markets', The Journal Financial and Quantitative Analysis, 35(2), 153-172.

9. Chopra, N., Lakonishok, J. and Ritter, J. R. (1992) 'Measuring Abnormal Performance - Do Stocks Overreact?', Journal of Financial Economics, 31, 235-268.

10. Claessens, S., Dasgupta, S. and Glen, J. (1998) 'The Cross-Section of Stock Returns: Evidence from Emerging Markets', Emerging Markets Quarterly, 12, 4-13.

11. De Bondt, W. F. M. and Thaler, R. H. (1985) 'Does the Stock Market Overreact?', Journal of Finance, 40(3), 793-805.

12. De Bondt, W. F. M. and Thaler, R. H. (1987) 'Further Evidence on Investor Overreaction and Stock Market Seasonality', Journal of Finance, 42(3), 557-581.

13. Drew, M. E. and Veeraraghavan, M. (2002) 'A Closer Look at the Size and Value Premium in Emerging Markets: Evidence from the Kuala Lumpur Stock Exchange', Asian Economic Journal, 16(4), 337-351.

14. Drew, M. E. and Veeraraghavan, M. (2003) 'A Closer Look at the Size and Value Premium in Emerging Markets: Evidence from the Kuala Lumpur Stock Exchange', Journal of the Asia Pacific Economy, 8(3), 354-379.

15. Fama, E. F. (1970) 'Efficient Capital Markets: A Review of Theory and Empirical Work', Journal of Finance, 25, 383-417.

16. Fama, E. F. (1991) 'Efficient Capital Markets: II', Journal of Finance, vol (5), 1575-1617.

17. Fama, E. F. and French, K. R. (1992) 'The Cross-Section of Expected Stock Returns', Journal of Finance, 47, 427-465.

18. Fama, E. F. and French, K. R. (1993) 'Common Risk Factors in the Returns on Stocks and Bonds', Journal of Financial Economics, 33(1), 3-56.

19. Fama, E. F. and French, K. R. (1996) 'Multifactor Explanations of Asset Pricing Anomalies', Journal of Finance, 51(4), 55-84.

20. Fama, E. F. and French, K. R. (1998) 'Value versus Growth: The International Evidence', Journal of Finance, 53(6), 1975-1999.

21. Fama, E. F. and MacBeth, J. (1973) 'Risk, Return, and Equilibrium', Journal of Political Economy, 81(3), 607-636.

22. Fraser, E. and Page, M. J. (2000) 'Value and Momentum Strategies: Evidence from the JSE', Investment Analysts Journal, 51, 25-35.

23. Gaunt, C. (2004) 'Size and Book to Market Effects and the Fama-French Three Factor Asset Pricing Model: Evidence from the Australian Stock-market', Accounting and Finance, 44, 27-44.

24. Hodnett, K (2010), 'Analysis of the Cross-Section of Equity Returns on the JSE Securities Exchange based on Linear and Nonlinear Modeling Techniques', Unpublished Doctoral Thesis, University of Cape Town

25. Hsieh, H (2010), 'Applications of Global Equity Style Indices in Active and Passive Portfolio Management', Unpublished Doctoral Thesis, University of Cape Town

26. Hsieh, H. and Hodnett, K (2011) 'Cross-Sector Style Analysis of Global Equities', International Business and Economics Research Journal, 10(11), 1-16.

27. Jegadeesh, N. and Titman, S. (1993) 'Returns to Buying Winners and Selling Losers: Implications for Stock Market Efficiency’, Journal of Finance, 48(1), 65-91.

28. Lakonishok, J., Shleifer, A. and Vishny, R. W. (1994) 'Contrarian Investment, Extrapolation and Risk', Journal of Finance, 49(5), 1541-1578.

29. Maroney, N. and Protopapadakis, A. (2002) 'The Book-to-Market and Size Effects in a General Asset Pricing Model: Evidence from Seven National Markets', European Finance Review, 6, 189-221.

30. Muller, C. (1999), 'Investor Overreaction on the Johannesburg Stock Exchange', Investment Analysts Journal, 49, 5-17.

31. Page, M. J. and Way, C. V. (1992/1993) 'Stock Market Overreaction: The South African Evidence', Investment Analysts Journal, 36, 35-49. 
32. Reinganum, M. R. (1981) 'Misspecification of Capital Asset Pricing - Empirical Anomalies Based on Earnings' Yields and Market Values', Journal of Financial Economics, 9, 19-46.

33. Reinganum, M. R. (1983) 'The Anomalous Stock Market Behaviour of Small Firms in January - Empirical Tests for Tax-Loss Selling Effects', Journal of Financial Economics, 12, 89-104.

34. Schiereck, D., De Bondt, W. F. M. and Weber, M. (1999) 'Contrarian and Momentum Strategies in Germany', Financial Analysts Journal, 55(6), 104-116.

35. Sharpe, W. F. (1964) 'Capital Asset Prices: A Theory of Market Equilibrium under Conditions of Risk', Journal of Finance, 19(3), 425-442.

36. Lintner, J. (1965) 'The Valuation of Risky Assets and the Selection of Risky Investments in Stock Portfolios and Capital Budgets', Review of Economics and Statistics, 47(1), 13-37. 